\title{
Mapping of Spatial Variability in Soil Properties and Soil Fertility for Site- Specific Nutrient Management in Bareli Watershed, Seoni District of Madhya Pradesh Using Geostatistics and GIS
}

\author{
Sagar N. Ingle ${ }^{1 *}$, M.S.S. Nagaraju ${ }^{2}$, Nisha Sahu², Rajeev Srivastava ${ }^{2}$, Pramod Tiwary ${ }^{2}$, \\ T.K. Sen ${ }^{2}$ and R.A. Nasre ${ }^{2}$ \\ ${ }^{1}$ Dr. Panjabrao Deshmukh Krishi Vidyapeeth Akola- 444104, India \\ ${ }^{2}$ ICAR-National Bureau of Soil Survey and Land Use Planning, Nagpur - 440033, India \\ *Corresponding author
}

\section{A B S T R A C T}

In this paper, spatial variability in soil chemical properties and fertility were investigated in Bareli watershed, Seoni district of Madhya Pradesh. Georefened soil samples with a grid spacing of $325 \times 325 \mathrm{~m}$ were collected in the study area and analyzed for soil $\mathrm{pH}$, organic

\section{Keywords}

Soil chemical properties, Soil fertility, Spatial variabililty, Kriged maps

Article Info

Accepted:

18 September 2018 Available Online: 10 October 2018 carbon, cation exchange capacity, available macronutrients $(\mathrm{N}, \mathrm{P}$ and $\mathrm{K})$ and micronutrients (Fe, $\mathrm{Mn}, \mathrm{Cu}$ and $\mathrm{Zn}$ ). Spatial variability was quantified through semivariogram analysis using geostatistics and kriged maps were generated in Geographic Information System (GIS). The results indicated that organic carbon was found to be highly variable followed by cation exchange capacity, while $\mathrm{pH}$ was found least variable. The soil fertility indicated that available $\mathrm{K}$ was found to be highly variable followed by available $\mathrm{P}$, while available $\mathrm{N}$ was found to be least variable. All the micronutrients showed moderate variability. The spatial maps indicated that the available $\mathrm{N}, \mathrm{P}$ and $\mathrm{K}$ were low to medium, medium to very high and medium to high, respectively. DTPA-Fe and DTPA-Zn was found deficient in $93.1 \%$ and $53.8 \%$ of area of the watershed. The reclassified kriged maps of soil fertility parameters generated from the point data clearly delineated different nutrient levels in the soils and very useful for site-specific nutrient management in the watershed.

\section{Introduction}

The productivity potential of soil varies with its fertility, inherent characteristics and environmental conditions. Understanding the spatial variability in soil properties and its interaction with soil fertility parameters is very important for site-specific nutrient management to improve the productivity. Soil properties change in time and space continuously (Rogerio et al., 2006). Determining soil variability is important for ecological modelling, environmental predictions, precise agriculture and management of natural resources (Hangsheng et al., 2005).

Geostatistical methods are essential for the investigation of spatial variations of soil and crop parameters across agricultural fields, 
which can lead to the efficient implementation of soil fertility management systems (Najafian et al., 2012). Furthermore, geostatistical methods have been adopted and used in sitespecific management applications, soil sampling strategies and assessment of farm management decisions. Semivariogram analysis in geostatistics is done to characterize and model spatial variance of data to assess how data points are related with separation distances, while, kriging uses modelled variance to estimate values between samples (Journel and Huijbregts, 1978).

The problems of declining soil fertility, low crop yield and accelerated soil erosion are associated implications for agricultural development since the bulk of agricultural production takes place under traditional systems, where, soil fertility is a key component. The result is poor farm management practices, low yield and an unnecessary high cost of production. The objective of this study is to assess the spatial variation in soil properties and soil fertility of a continuously cultivated land under rainfed systems using GIS for site-specific nutrient management.

\section{Materials and Methods}

The Bareli watershed in basaltic terrain lies between $22^{\circ} 29^{\prime} 39^{\prime \prime}$ to $22^{\circ} 32^{\prime} 10^{\prime \prime} \mathrm{N}$ latitude and $79^{\circ} 46^{\prime} 44^{\prime \prime}$ to $79^{\circ} 49^{\prime} 50^{\prime \prime} \mathrm{E}$ longitude and covers an area of 1795.35 ha in Dhanora block, Seoni district, Madhya Pradesh. Physiographically, Bareli watershed was divided into five major physiographic units viz. plateau $(\mathrm{P})$, escarpments $(\mathrm{E})$, hills and ridges $(\mathrm{H})$, isolated mounds $(\mathrm{M})$ and pediments (D). The elevation of the area ranges from 520 to $620 \mathrm{~m}$ above mean sea level (MSL). The area is associated with level to nearly level sloping (0-1\%) to moderately steep to steeply sloping (15-25\%) lands. The climate is mainly dry sub-tropical with mean annual temperature of $28.4^{\circ} \mathrm{C}$ and mean annual rainfall of $1100 \mathrm{~mm}$. The area qualifies for ustic soil moisture regime and hyperthermic soil temperature regime. The natural vegetation comprises of teak (Tectona grandis), babul (Acacia spp.), palas (Butea frandosa), charoli (Buchanania lanzan), ber (Ziziphus jujuba) etc. The major crops are paddy (Oryzasativa), pigeonpea (Cajanus cajan), maize (Zea mays) and safflower (Carthamus tinctorius) in kharif and wheat (Triticum aestivum) and gram (Cicer arietinum) in rabi under irrigation or stored moisture. Mango and Guava are the main fruit crops of the area (Fig. 1 and 2).

Survey of India (SOI) toposheets No. 55 N/14 and $55 \mathrm{~N} / 15$ (1:50000 scale) and IRS-P6 LISS-IV data (November, 2013) were georeferenced using WGS 84 zone $44 \mathrm{~N}$ datum, Universal Transverse Mercator (UTM) projection to collect topographic and location information. Georeferenced soil samples (0$15 \mathrm{~cm}$ ) were collected using the grid method. A grid interval of 325 by $325 \mathrm{~m}$ was laid on the georeferenced toposheet and satellite data and used for collection of soil samples. A total of 129 soil samples were collected from the study area. The soil samples collected during the field work were processed, screened through $2 \mathrm{~mm}$ sieve, properly labeled and stored in polythene bags for laboratory analysis. Soil samples were analyzed for $\mathrm{pH}$, organic carbon, cation exchange capacity and available $\mathrm{N}, \mathrm{P}, \mathrm{K}, \mathrm{Fe}, \mathrm{Mn}, \mathrm{Cu}$ and $\mathrm{Zn}$ following the standard procedures (Black 1965; Jackson 1967).

The datasets containing measured soil variables were statistically analyzed using classical statistical method to obtain minimum, maximum, mean, standard deviation (SD), coefficient of variation (CV), skewness, kurtosis using SPSS version 11.5 software. The data was normalized before interpolation to generate surface maps of soil 
properties. In the study, logarithmic transformation functions available in Geostatistical Analyst of ArcGIS software (version 10.1) were applied to normalize the data wherever the data sets of soil properties were found to be non-normal. Surface maps of basic soil properties and soil fertility were prepared using semivariogram parameters through ordinary kriging in geostatistical analyst of ArcGIS software.

\section{Results and Discussion}

The descriptive statistics of soil chemical properties (Table 1) indicated that $\mathrm{pH}$ varied from 6.1 to 7.8 and organic carbon varied from 0.38 to 1.94 per cent with a mean value of 1.08. Cation exchange capacity (CEC) varied from 24.3 to $57.3 \mathrm{cmol}\left(\mathrm{p}^{+}\right) \mathrm{kg}^{-1}$ with a mean value of $43.6 \mathrm{cmol}\left(\mathrm{p}^{+}\right) \mathrm{kg}^{-1}$. Among the chemical properties studied, organic carbon was found to be highly variable $(\mathrm{CV}=0.29)$ followed by cation exchange capacity $(\mathrm{CV}=$ $0.18)$, while $\mathrm{pH}$ was found least variable (CV $=0.05)$. The descriptive statistics of soil fertility parameters (Table 1) indicated that available $\mathrm{N}, \mathrm{P}$ and $\mathrm{K}$ varied from 125.4 to $464.1,11.6$ to 59.1 and 56 to $986.8 \mathrm{~kg} \mathrm{ha}^{-1}$ with mean value of $263.4 \mathrm{kgha}^{-1}, 30.8 \mathrm{kgha}^{-1}$ and $390.7 \mathrm{kgha}^{-1}$, respectively. The DTPA micronutrient cations $\mathrm{Fe}, \mathrm{Mn}, \mathrm{Cu}$ and $\mathrm{Zn}$ varied from 0.45 to $27.3,1.17$ to $41.1,2.24$ to 89.7 and 0.14 to $1.62 \mathrm{mgkg}^{-1}$ soil with mean values of $7.94,19.0,12.3$ and $0.56 \mathrm{mgkg}^{-1}$ soil, respectively. Among the macronutrients, available $\mathrm{K}$ was found to be highly variable $(\mathrm{CV}=0.48)$ followed by available $\mathrm{P}(\mathrm{CV}=$ 0.36 ). Available $\mathrm{N}$ was found to be least variable $(\mathrm{CV}=0.23)$. All the micronutrients were moderately variable with $\mathrm{CV}$ ranging from 0.50 to 0.89 .

The reclassified maps of soil $\mathrm{pH}$, organic carbon and cation exchange capacity are presented in figure 3, respectively. Spatial variability map of soil $\mathrm{pH}$ indicated that it varied from 6.5 to 7.2. The spatial map of soil $\mathrm{pH}$ was reclassified into slightly acidic $(\mathrm{pH}$ : 6.5-6.8) and neutral ( $\mathrm{pH}$ 6.8-7.2). Different soil $\mathrm{pH}$ classes (Table 2) indicated that majority of area is under slightly acidic (62.7\% of TGA) followed by neutral (36.9\% of TGA). Spatial variability map of soil organic carbon varied from 0.38 to 1.94 per cent. The spatial variability map of organic carbon was reclassified into medium (0.4$0.6 \%)$, moderate $(0.6-0.8 \%)$, high $(0.8-1.0 \%)$ and very high $(>1.0 \%)$. Soil organic carbon classes (Table 2) indicated that majority of area is under high (37.3\% of TGA) followed by moderate (27.5\% of TGA), very high (22.2\% of TGA) and medium (12.4\% of TGA). Spatial variability map of cation exchange capacity indicated that it varied from 24.3 to $57.3 \mathrm{cmol}(\mathrm{p}+) \mathrm{kg}^{-1}$ soil. The spatial variability map of cation exchange capacity was reclassified in to 3 classes viz. 33-41, 41-49 and $49-57 \mathrm{cmol}(\mathrm{p}+) \mathrm{kg}^{-1}$.

The reclassified maps of available $\mathrm{N}, \mathrm{P}$ and $\mathrm{K}$ are presented in figure 4 , respectively. The kriged maps of available $\mathrm{N}, \mathrm{P}$ and $\mathrm{K}$ indicated that available $\mathrm{N}$ varied from 125 to $280 \mathrm{~kg}$ $\mathrm{ha}^{-1}, 17$ to $51 \mathrm{~kg} \mathrm{ha}^{-1}$ and 118 to $677 \mathrm{~kg} \mathrm{ha}^{-1}$, respectively. The kriged map of available $\mathrm{N}$ was reclassified in to very low $\left(<140 \mathrm{~kg} \mathrm{ha}^{-1}\right)$, low (141-280 kg ha ${ }^{-1}$, medium (281-420 kg $\left.\mathrm{ha}^{-1}\right)$, moderately high (421-560 $\left.\mathrm{kg} \mathrm{ha}^{-1}\right)$, high $\left(561-700 \mathrm{~kg} \mathrm{ha}^{-1}\right)$ and very high $(>700 \mathrm{~kg}$ $\mathrm{ha}^{-1}$ ). The data indicated (Table 2) that available $\mathrm{N}$ indicated that entire area of watershed was found low to medium in available $\mathrm{N}$. The kriged map of available $\mathrm{P}$ was reclassified in to very low $\left(<7.0 \mathrm{~kg} \mathrm{ha}^{-1}\right)$, low (7.1-14.0 kg ha $\left.{ }^{-1}\right)$, medium (14.1-21.0 kg $\left.\mathrm{ha}^{-1}\right)$, moderately high (21.1-28.0 $\left.\mathrm{kg} \mathrm{ha}^{-1}\right)$, high (28.1-35.0 $\left.\mathrm{kg} \mathrm{ha}^{-1}\right)$ and very high (>35.0 $\mathrm{kg} \mathrm{ha}^{-1}$ ). The data (Table 2) indicated that majority area of the watershed was found to be medium in available $\mathrm{P}(35.1 \%$ of TGA) followed by high ( $34.8 \%$ of TGA) and very high (29.7\% of TGA) (Table 2). 
Table.1 Descriptive statistics of soil chemical properties and soil fertility

\begin{tabular}{|c|c|c|c|c|c|c|c|}
\hline Soil property & Minimum & Maximum & Mean & $\begin{array}{l}\text { Standard } \\
\text { deviation }\end{array}$ & $\mathbf{C V}$ & Skewness & Kurtosis \\
\hline pH & 6.1 & 7.8 & 6.7 & 0.39 & 0.05 & 0.48 & -0.50 \\
\hline $\mathrm{OC}(\%)$ & 0.38 & 1.94 & 1.08 & 0.32 & 0.29 & 0.13 & -0.60 \\
\hline CEC (cmolp+kg $\left.{ }^{-1}\right)$ & 24.3 & 57.3 & 43.6 & 8.05 & 0.18 & -0.27 & -0.76 \\
\hline Available $\mathrm{N}\left(\mathrm{kg} \mathrm{ha}^{-1}\right)$ & 125.4 & 464.1 & 263.4 & 63.1 & 0.23 & 0.43 & 0.19 \\
\hline Available P $\left(\mathrm{kg} \mathrm{ha}^{-1}\right)$ & 11.6 & 59.1 & 30.8 & 11.3 & 0.36 & 0.68 & -0.30 \\
\hline Available K $\left(\mathrm{kg} \mathrm{ha}^{-1}\right)$ & 56 & 986.8 & 390.7 & 189.9 & 0.48 & 0.75 & 0.20 \\
\hline Available Fe (mg kg-1) & 0.45 & 27.3 & 7.94 & 6.12 & 0.77 & 1.11 & 0.64 \\
\hline Available Mn (mg kg $\left.{ }^{-1}\right)$ & 1.17 & 41.1 & 19.0 & 9.51 & 0.50 & 0.19 & -0.74 \\
\hline Available $\mathrm{Cu}\left(\mathrm{mg} \mathrm{kg}^{-1}\right)$ & 2.24 & 89.7 & 12.3 & 11.0 & 0.89 & 4.5 & 25.7 \\
\hline A vailable $\mathrm{Zn}\left(\mathrm{mg} \mathrm{kg}^{-1}\right)$ & 0.14 & 1.62 & 0.56 & 0.28 & 0.50 & 1.0 & 1.3 \\
\hline
\end{tabular}

Table.2 Spatial distribution pattern of soil chemical properties and soil fertility

\begin{tabular}{|c|c|c|c|}
\hline Class & Range & Area (ha) & $\%$ of TGA \\
\hline \multicolumn{4}{|c|}{ pH } \\
\hline Slightly acidic & $6.5-6.8$ & 1127.0 & 62.78 \\
\hline Neutral & $6.8-7.2$ & 663.68 & 36.97 \\
\hline \multicolumn{4}{|c|}{ Organic carbon (\%) } \\
\hline Medium & $0.4-0.6$ & 223.5 & 12.4 \\
\hline Moderate & $0.6-0.8$ & 498.2 & 27.5 \\
\hline High & $0.8-1.0$ & 669.5 & 37.3 \\
\hline Very high & $>1.0$ & 399.3 & 22.2 \\
\hline \multicolumn{4}{|c|}{ A vailable $\mathrm{N}\left(\mathrm{kg} \mathrm{ha} \mathrm{a}^{-1}\right)$} \\
\hline Low & $125-280$ & 1595.5 & 88.8 \\
\hline Medium & $280-464$ & 195.1 & 10.8 \\
\hline \multicolumn{4}{|c|}{ Available $P\left(\mathrm{~kg} \mathrm{ha}^{-1}\right)$} \\
\hline Medium & $17-25$ & 629.9 & 35.1 \\
\hline High & $25-34$ & 625.9 & 34.9 \\
\hline Very high & $34-51$ & 534.8 & 29.8 \\
\hline \multicolumn{4}{|c|}{ Available $\mathrm{K}\left(\mathrm{kg} \mathrm{ha}^{-1}\right)$} \\
\hline Medium & $118-258$ & 345.9 & 19.3 \\
\hline High & $258-677$ & 1444.6 & 80.4 \\
\hline \multicolumn{4}{|c|}{ Available $\mathrm{Zn}\left(\mathrm{mg} \mathrm{kg-}^{-1}\right)$} \\
\hline Deficient & $<0.6$ & 966.8 & 53.8 \\
\hline Sufficient & $>0.6$ & 823.8 & 45.8 \\
\hline \multicolumn{4}{|c|}{ Available $\mathrm{Fe}\left(\mathrm{mg} \mathrm{kg}^{-1}\right)$} \\
\hline Deficient & $<4.5$ & 369.5 & 20.5 \\
\hline Sufficient & $>4.5$ & 1421.1 & 79.1 \\
\hline
\end{tabular}


Fig.1 Location of study area

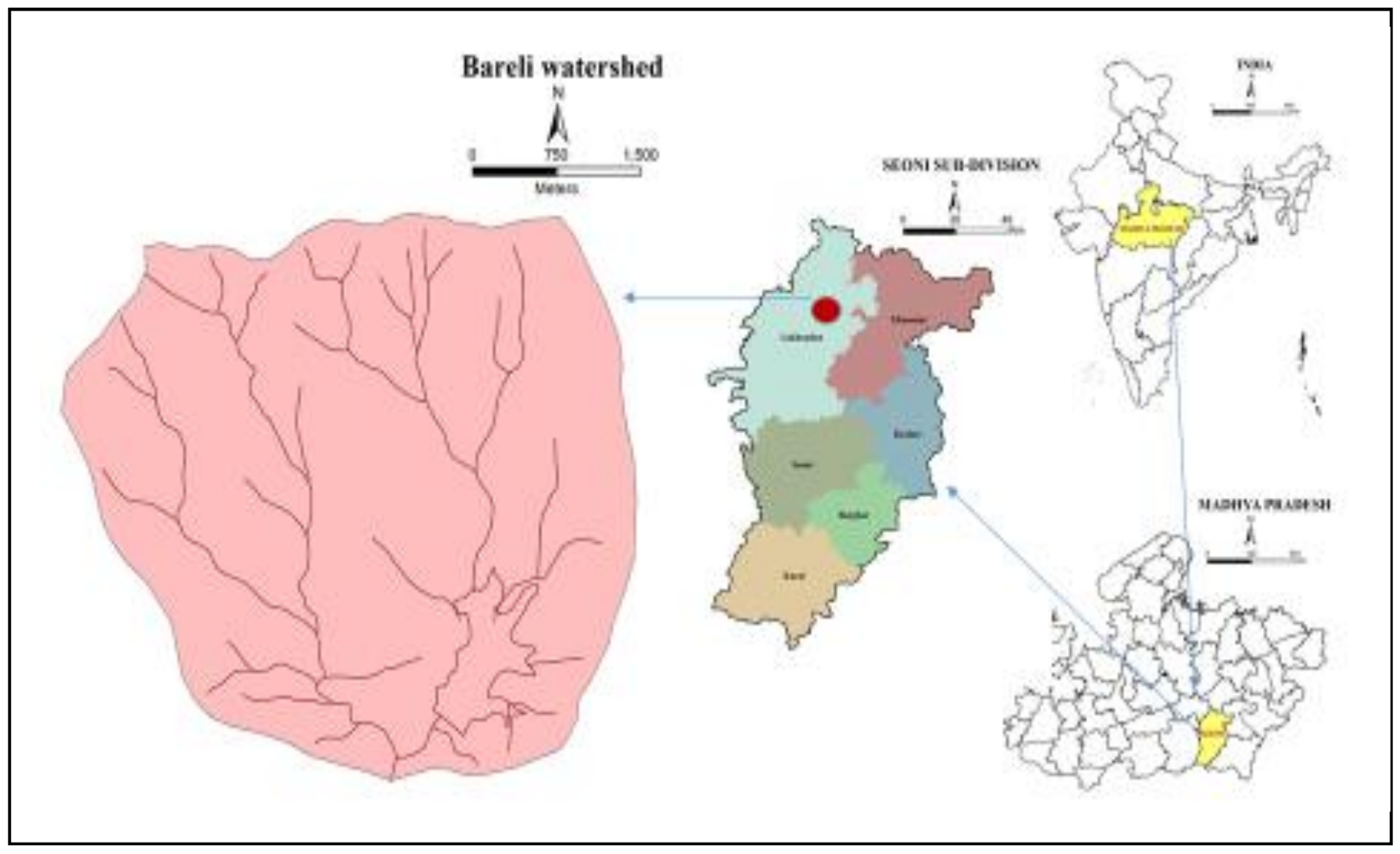

Fig.2 Soil sampling design

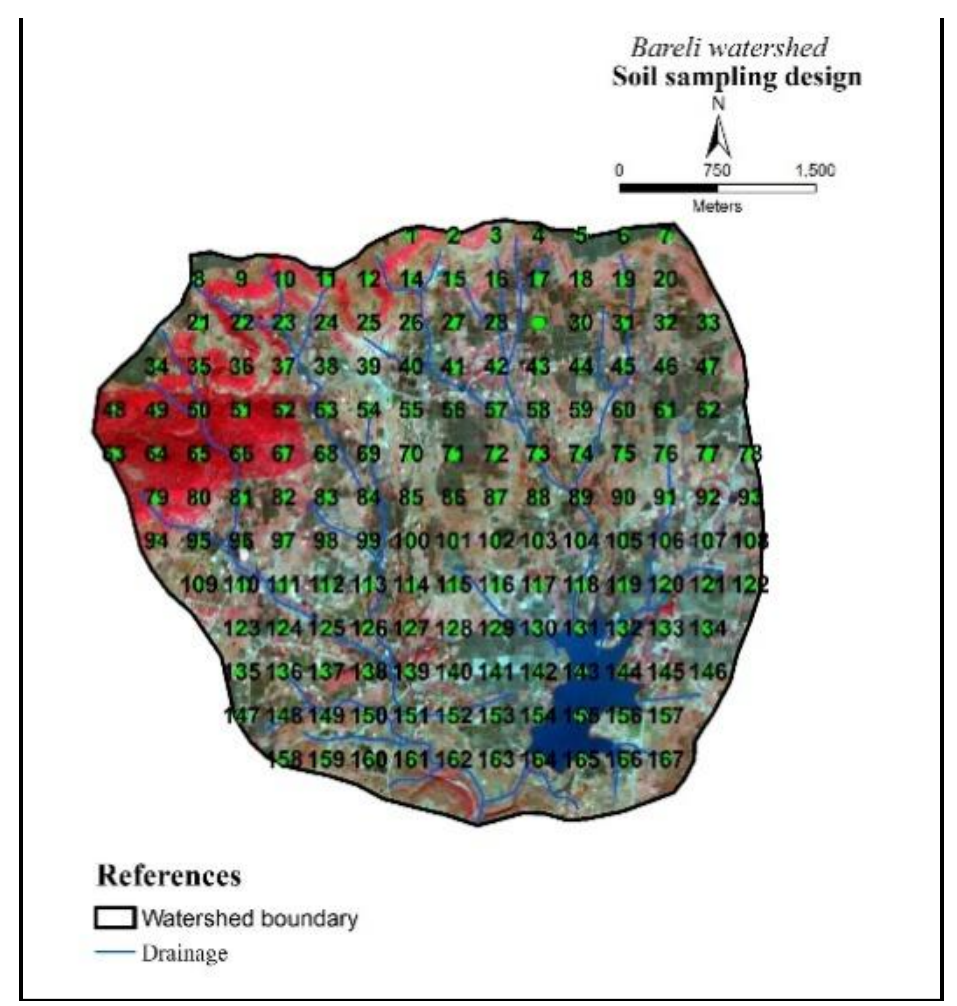



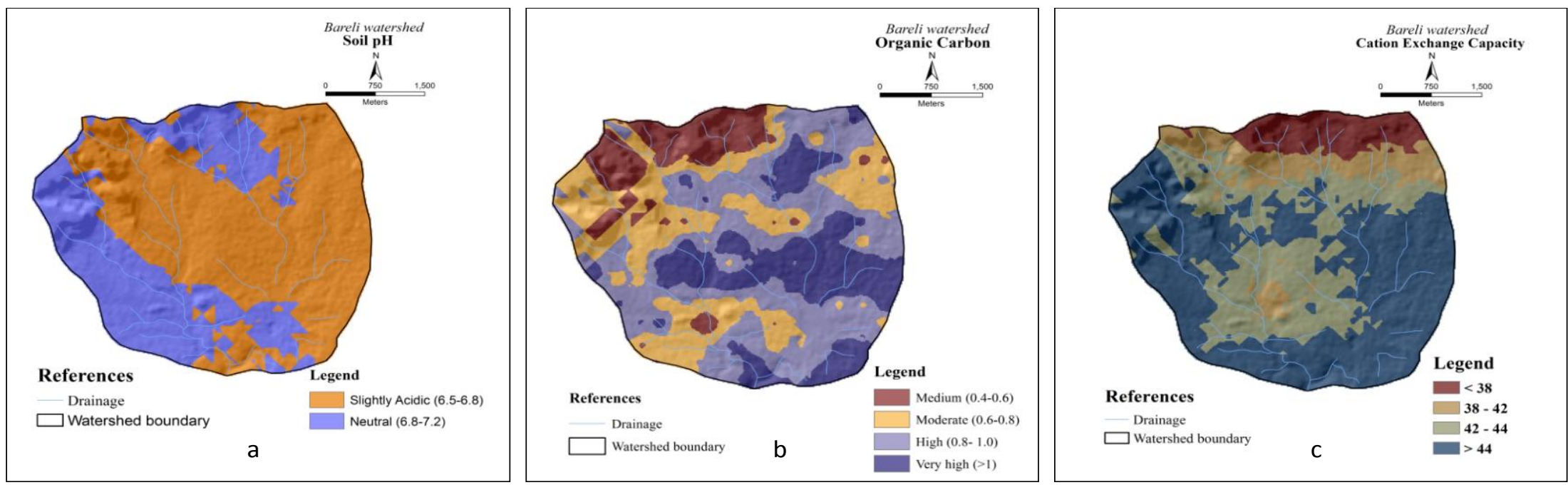

Fig. 3 Kriged maps of a) soil $\mathrm{pH}, \mathrm{b}$ ) organic carbon and c) cation exchange capacity
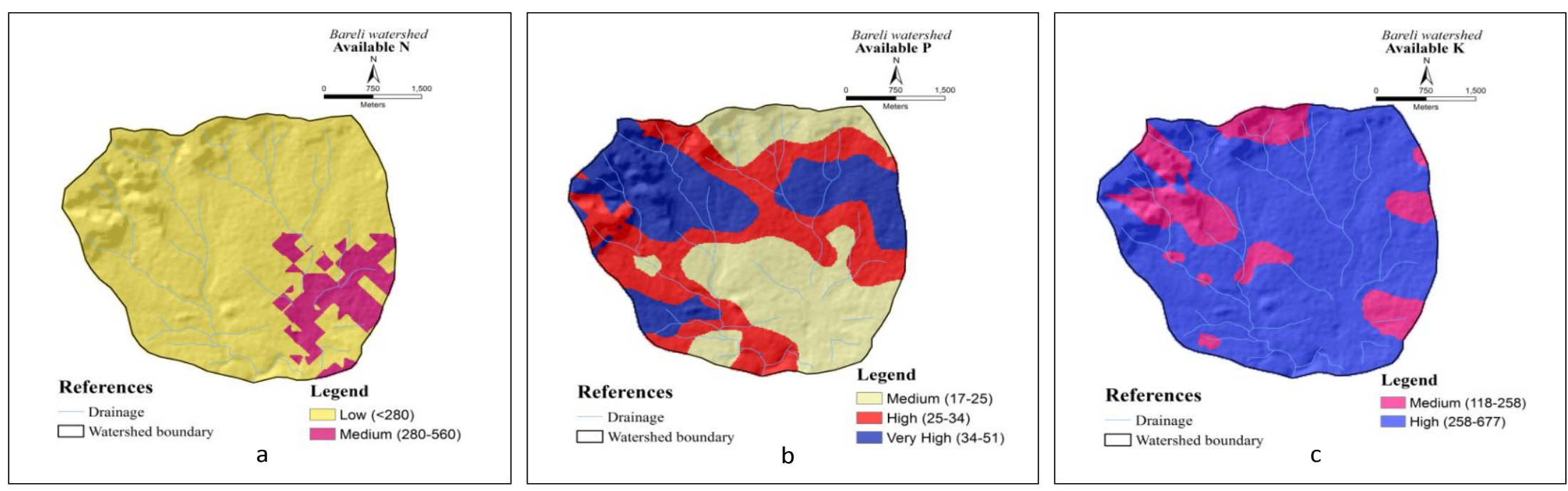

Fig. 4 Kriged maps of a) available N, b) available $\mathrm{P}$ and c) available $\mathrm{K}$ 

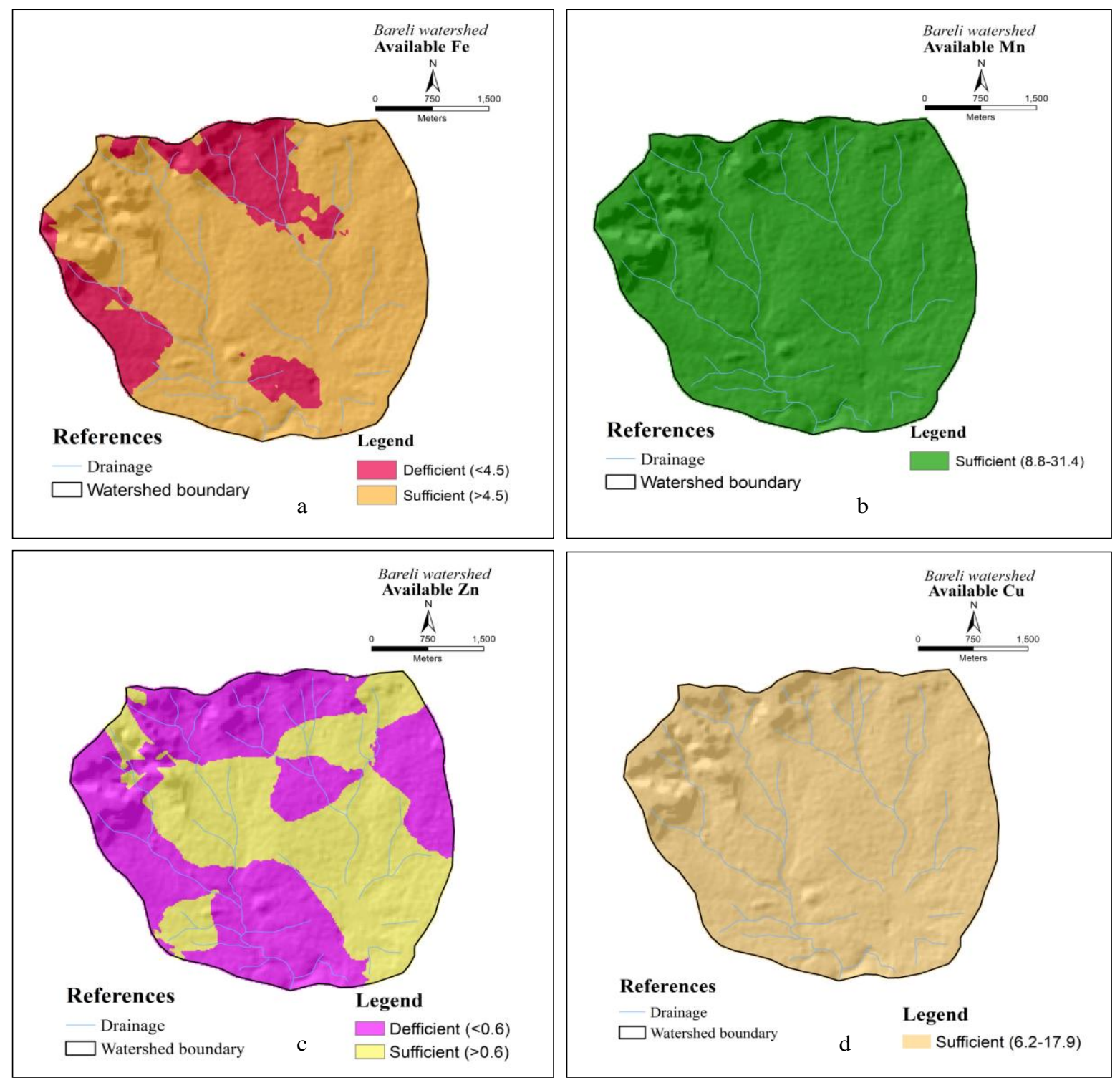

Fig. 5Kriged maps of a) DTPA-Fe, b) DTPA-Mn, c) DTPA-Cu and d) DTPA-Zn

The kriged map of available $\mathrm{K}$ was reclassified in to very low $\left(<100 \mathrm{~kg} \mathrm{ha}^{-1}\right)$, low (100-150 kg ha-1), medium (151-200 kg ha-1), moderately high (201-250 $\left.\mathrm{kg} \mathrm{ha}^{-1}\right)$, high (251$\left.300 \mathrm{~kg} \mathrm{ha}^{-1}\right)$ and very high (>300 $\left.\mathrm{kg} \mathrm{ha}^{-1}\right)$. The data (Table 2) indicated that majority of area is under high ( $80.4 \%$ of TGA) followed by medium (19.3\% of TGA).

The reclassified spatial kriged maps of available micronutrients are presented in figure 5. Spatial map of DTPA-Fe showed that DTPA-Fe varied from 0.45 to $27.3 \mathrm{mg}$ $\mathrm{kg}^{-1}$ soil and reclassified in to deficient and sufficient areas against the critical level of 4.5 $\mathrm{mg} \mathrm{kg}^{-1}$ soil (Lindsey and Norvell, 1978) and $20.5 \%$ of TGA was found deficient in DTPAFe (Table 2). Spatial map of DTPA-Mn showed that DTPA-Mn varied from 3.15 to $41.1 \mathrm{mg} \mathrm{kg}^{-1}$ soil and found to be much higher than the critical level of $3.0 \mathrm{mg} \mathrm{kg}^{-1}$ soil (Takkar et al., 1989). Spatial map of DTPA$\mathrm{Cu}$ showed that DTPA-Cu spatially varied from 1.34 to $19.0 \mathrm{mg} \mathrm{kg}^{-1}$ soil and was found 
higher than the critical value of $0.2 \mathrm{mg} \mathrm{kg}^{-1}$ soil (Katyal and Randhawa, 1983). Spatial map of DTPA-Zn showed that DTPA-Zn varied from 0.14 to $1.62 \mathrm{mg} \mathrm{kg}^{-1}$ soil and reclassified in to deficient and sufficient areas against the critical level of $0.6 \mathrm{mg} \mathrm{kg}{ }^{-1}$ soil (Katyal and Randhawa, 1983; Sharma et al., 1996) and the data (Table 2) indicated that majority of area was found deficient in DTPA-Zn (53.8\% of TGA).

The spatial variability in soil properties and fertility was quantified through semivariogram analysis and the respective surface maps were prepared through ordinary kriging in Bareli watershed. The study helped to identify and delineate critical nutrient sufficiency and deficiency areas. The spatial maps indicated that the available $\mathrm{N}, \mathrm{P}$ and $\mathrm{K}$ were low to medium, medium to very high and medium to high, respectively. DTPA-Fe and DTPA-Zn was found deficient in $93.1 \%$ and $53.8 \%$ of area of the watershed. The generated maps can serve as an effective tool for site-specific nutrient management. This is a prerequisite in order to optimize the cost of cultivation as well as to address nutrient deficiency.

\section{References}

Black, C.A., Evans, D.D White, J.L. Ensmingel, L.E. and Clark, F.E. (eds). 1965. Methods of soil analysis, Part I. American Soc. of Agron., No. 9, Madison, WI.
Hangsheng L., Dan W., Jay B., and Larry W., 2005, Assessment of soil spatial variability at multiple scales. Ecological Modelling 182, 271-290

Jackson, M.L. 1967. Soil Chemical Analysis. Prentice Hall, New Delhi.

Journel, A. G. and Ch. J. Huijbregts, 1978. Mining Geostatistics. Academic Press, London, $600 \mathrm{pp}$.

Katyal, J.C. and N.S. Randhawa 1983. In: Micronutrients. FAO fertilizer and plant nutrition bulletin, Rome 5: $92 \mathrm{p}$.

Lindsay, W.L. and Norvel, L.W.A. 1978. Development of DTPA soil test zinc, iron, manganese and copper. Soil Science Society of America Journal42: 421-448.

Najafian, A., Dayani, M., Motaghian, H.R., Nadian, H., 2012. Geostatistical assessment of the spatial distribution of some chemical properties in calcareous soils. J. Integr. Agric. 11 (10), 17291737.

Rogerio, C., Ana, L. B. H., \& de Quirijn, J. L. 2006. Spatiotemporal variability of soil water tension in a tropical soil in Brazil. Geoderma, 133, 231-243.

Sharma, S.S., K.L. Totawat and R.L. Shyampura, 1996. Characterization and classification of soils in toposequence over basaltic terrain Journal of Indian Society of Soil Science, 44(3) 470-475.

Takkar, P.N., Chhibba I.M. and Mehta, S.K. 1989. Twenty years of coordinated research on micronutrients in soil and plant. Bull., Indian Institute of Soil Science, Bhopal, 75p.

\section{How to cite this article:}

Sagar N. Ingle, M.S.S. Nagaraju, Nisha Sahu, Rajeev Srivastava, Pramod Tiwary, T.K. Sen and Nasre, R.A. 2018. Mapping of Spatial Variability in Soil Properties and Soil Fertility for SiteSpecific Nutrient Management in Bareli Watershed, Seoni District of Madhya Pradesh Using Geostatistics and GIS. Int.J.Curr.Microbiol.App.Sci. 7(10): 2299-2306.

doi: https://doi.org/10.20546/ijcmas.2018.710.266 